\title{
Snakes or Ladders? Measuring the Intergenerational Performance of Chosŏn's Munkwa Exam Candidates*
}

Robin Wooyeong Na**, Javier Cha***

\section{Introduction}

This interdisciplinary study measures the changes in intergenerational exam performance using a model of directed centrality values. Our test case explores the approximately 14,600 higher civil examination degree holders in the Academy of Korean Studies edition of the Munkwa data-

* This study was supported by the Seoul National University Big Data Institute's 2019 Grant for the Promotion of Data Science (0660-20190012). We would like to express our gratitude to Lee Jaeok [MR: Yi Chaeok] of the Academy of Korean Studies for making his Munkwa database available for other researchers and Choi Donghyeok [MR: Ch'oe Tonghyŏk] at KAIST for preprocessing the data set.

Special thanks go to Malcolm Thompson and Allison Van Deventer for copyediting several versions of this article manuscript and the two anonymous reviewers and John S. Lee for their helpful comments.

The Python code and the data sets used in this study are available at: https://githu b.com/robin-na/snakes-or-ladders

** Equal contribution. College of Liberal Studies, Seoul National University, robinna@snu.ac.kr

*** Corresponding author. Equal contribution. Assistant Professor of East Asian Studies, College of Liberal Studies, Seoul National University \& Digital Historian-inResidence, Department of History, Lingnan University, javiercha@snu.ac.kr 
base (Munkwa pangmok 文科榜目), in particular the underutilized records about each candidate's agnatic and affinal relations, up to three generations above him. Despite some imperfections in the Munkwa database and the genealogical materials added to it, we propose a novel way of querying the connections between micro-level events and long-term structural historical changes. For instance, we examine the degree to which early modern Korea's turn toward oligarchy and stratification should be understood as a consequence of an exogenous shock or as an acceleration of pre-existing developments. ${ }^{1}$ In addition, from a social network perspective and using the Munkwa data as a proxy, we can measure the degree of social fluidity in early modern Korean society at specific historical conjunctures as well as identify exceptionally high-and low-performing family branches. The network model, data structure, and Python code developed for this study can be applied to other kinship and genealogical materials from the Chosŏn dynasty 朝鮮 (1392-1910) and elsewhere.

Our data-driven narrative demonstrates what historians have suspected for a long time. In tenth-century Korea, an indigenous sociopolitical order based almost exclusively on birth rights collapsed. ${ }^{2}$ In the system that arose from this, talented individuals were required to participate in highly competitive government examinations to qualify for appointments in the central bureaucracy. ${ }^{3}$ At first, these examinations tested candidates in a

1 JaHyun Kim Haboush, "Constructing the Center: The Ritual Controversy and the Search for a New Identity" in Culture and the State in Late Chosón Korea, 50, argues that the wars with Japan in 1592 and 1597 and the Manchu invasions of 1627 and 1636 challenged "the very basis of the Korean episteme of world and self." For perspectives that emphasize pre-existing developments, see Yi Sugŏn, Yŏngnam sarimp'a ŭi hyŏngsŏng (Kyŏngsan: Yŏngnam taehakkyo ch'ulp'anbu, 1990); Miyajima Hiroshi, Yangban: Uri ka mollat tŏn yangban ŭi silch'e rŭl ch'ajasŏ Seoul: Nŏmŏ Puksŭ, 2014), especially 40-123; and Javier Cha, "To Build a Centralizing Regime: Yangban Aristocracy and Medieval Patrimonialism," Seoul Journal of Korean Studies 32, no.1 (June 2019): 35-80.

2 Javier Cha, "To Build a Centralizing Regime," 36-38.

3 Hŏ Hŭngsik, Koryŏ ŭi kwagŏ chedo (Seoul: Ilchogak, 2005). 
range of fields, such as medical knowledge, technical expertise, and Buddhist doctrine. ${ }^{4}$ Over time, central bureaucratic offices tended to be given more to those who demonstrated their potential in either civil administration based on Confucian classical training or the military arts. In a society in which birth mattered but did not necessarily guarantee status, one's standing depended on service in one of eighteen ranked civil or military offices known as "the two orders," or yangban 兩班. James Palais refers to this peculiar relationship between heredity and merit as a balance between aristocracy and bureaucracy, which, he argues, contributed to the longevity of premodern Korean political regimes. ${ }^{5}$

From the eleventh to the nineteenth centuries, Koreans regarded education as a key ladder for upward mobility, as the state examinations were the principal entryway to yangban officialdom. The legal system recognized only two statuses: commoners (yangin 良人) and the lowborn (ch'ónin 賤人). In theory, the state examinations were open to all male commoners. ${ }^{6}$ A small number of commoners managed to pass the examinations and were given the opportunity to enter the yangban. ${ }^{7}$ On the other hand, education also served as a means of affirming social distinction, especially during periods of widespread downward mobility and social stratification. Since the yangban were de facto aristocrats but had no legal protection of their status, lifelong bureaucratic promotions, distinguished service, and ennoblement did not guarantee that a yangban's descendants would be recognized as highborn without their own yangban assignment. For a yangban's offspring to remain yangban, regular attainment of examination degrees across generations was essential, especially

4 Hŏ Hŭngsik, Koryŏ ŭi kwagŏ chedo.

5 James Palais, "Confucianism and the Aristocratic/Bureaucratic Balance in Korea," Harvard Journal of Asiatic Studies 44, no.2 (December 1984): 427-468.

6 Ch'oe Yongho, "Commoners in Early Yi Dynasty Civil Examinations: An Aspect of Korean Social Structure, 1392-1600," Journal of Asian Studies 33, no.4 (August 1974): 611-631.

7 Han Yŏngu, Kwagŏ: ch’ulse ŭi sadari (P’aju: Chisik sanŏpsa, 2013); Ch’oe Yongho, "Commoners in Early Yi Dynasty." 
degrees from the civil examinations that evaluated a candidate's command of Confucian scholarship. Some exceptions to this rule existed,

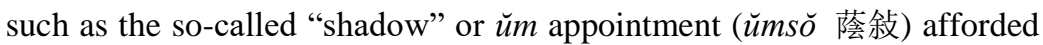
to the sons of yangban officials, but the beneficiaries of such privileges were expected eventually to prove their ability through performance in the examinations. ${ }^{8}$ The overarching concern of our study is to show how this dynamic can be represented quantitatively.

Our research provides a robust way of measuring the conditional distribution of a degree-holder's lineage survival on the basis of the examination performance of his ancestors. We pay particularly close attention to the sixteenth century, which has been identified as a turning point in Korean history in the works of Han Yŏngu, Yi T'aejin, Miyajima Hiroshi, and others. ${ }^{9}$ In the fifteenth and sixteenth centuries, a certain number of gifted commoners passed the munkwa 文科 examinations and could aspire to join the ranks of the yangban. ${ }^{10}$ In later times, however, the non-yangban population's chances of upward social mobility were greatly reduced as yangban households prioritized lineage survival and fought against the various forces that threatened their status and privilege. ${ }^{11}$ This broad pattern has been recognized by historians of Korea through studies of agricultural technology, land reclamation projects, demographic change, and slavery. ${ }^{12}$ Our provisional findings, in spite of some imperfections in the data, demonstrate statistically that the devastating Imjin War may have indeed been the watershed event responsible for the emergence of a new social order in sev-

8 Pak Yongun, Koryŏ sidae ŭmsŏje wa kwagŏje yŏn'gu (Seoul: Ilchisa, 1990).

9 Han Yŏngu, Kwagŏ. Miyajima Hiroshi, Yangban. Yi T'aejin, "16-segi yŏnhae chiyŏk ŭi ŏnjŏn kaebal: ch’ŏksin ch'ŏngch'i ŭi kyŏngje chŏk paegyŏng iltan,” Han'guk sahoesa yŏn'gu (Seoul: Chisik sanŏpsa, 1986).

10 Han Yŏngu, Kwagŏ. Ch'oe Yong-Ho, "Commoners in Early Yi Dynasty."

11 Yi Sŏngmu. Han'guk ŭi kwagŏ chedo (Seoul: Chimmundang, 1994). Eugene Y. Park, Between Dreams and Reality: The Military Examinations in Late Chosŏn Korea, 1600-1894 (Cambridge: Harvard University Asia Center, 2007).

12 Miyajima Hiroshi, Yangban. Yi T'aejin, "16-segi yŏnhae chiyŏk.” Kim Kŏnt'ae, Chosŏn sidae yangban'ga ŭi nongŏp kyŏngyŏng (Seoul: Yŏksa pip’yŏngsa, 2004). 
enteenth- and eighteenth-century Korea. ${ }^{13}$

\section{The Munkwa Database}

Originally developed to study the structure of the elites of the Chosŏn dynasty, the Munkwa database is a complete digital roster of the Chosŏn dynasty's munkwa holders. The unusual longevity of the Chosonn regime means that we have longitudinal records with nearly uninterrupted coverage of over five hundred years. ${ }^{14}$ Researchers at Harvard University began to compile the roster, which survived into the modern period in fragments, into a comprehensive collection in the 1960s, and it was then digitized into a database. ${ }^{15}$ Edward Wagner and Song June-ho [MR: Song Chunho] used the Munkwa database to demonstrate the power-law distribution of exam performance by choronym (pon'gwan 本貫) and the uneven distribution of examination degrees by region. ${ }^{16}$ Using aggregation

13 Kim Haboush JaHyun, The Great East Asian War and the Birth of the Korean Nation (New York: Columbia University Press, 2016); Hur Nam-lin, "Works in English on the Imjin War and the Challenge of Research," International Journal of Korean History 18, no.2 (August 2013): 53-80.

14 Pak Hyŏnsun, “Kukcho munkwa pangmok ŭi p'yŏnch'an kwa 18-segi inmul chŏngbohak," Kyujanggak 56 (June 2020): 173-215 is a landmark study of the collection of records we now refer to as the Munkwa Pangmok. When using the various digital editions of the Munkwa Pangmok, it is important to be mindful that this database has a complex history. For instance, the pre-1600 portions are likely a post-Imjin War reconstruction, and multiple official and commercial editions were in circulation before Edward Wagner, Song June-ho, and researchers at the Academy of Korean Studies produced standardized editions.

15 Javier Cha, "Digital Korean Studies: Recent Advances and New Frontiers," Digital Library Perspectives 34, no.3 (August 2018): 229; Sun Joo Kim, "The WagnerSong Munkwa Project and Its Legacy in the Research of Korean History," (unpublished); Song Mano, "The Wagner-Song Munkwa Project: Its Value for Historical Research,” Chŏnbuk sahak 32 (April 2008): 205-10.

16 Edward W. Wagner, "The Ladder of Success in Yi Dynasty Korea," Occasional 
and pivot tables, these studies have provided valuable cross-sectional observations of inequality using categorized records. The Wagner-Song Munkwa Project incorporated additional data from genealogies and local gazetteers so that one day this organic network could be mapped. ${ }^{17}$ The Munkwa database has proven robust enough to be used to analyze the social processes affecting the changing ladders of success in Korean society across time.

As a result of a dispute among historians of Korea, an alternative digital project was launched in the 1980s at the Academy of Korean Studies (AKS) in South Korea. Both the Harvard and the AKS editions have undergone several rounds of revision by experts, including Song Mano at Jeonju University, Lee Jaeok at the Academy of Korean Studies, and Park Hyun Soon [MR: Pak Hyŏnsun] at Seoul National University, resulting in more databases. Nonetheless, the original Wagner-Song vision of collating basic biographical information, addresses, choronym, and kinship data from genealogies, local gazetteers, and miscellaneous materials is followed in all these competing databases. Thus, the Munkwa database exists currently in multiple versions, and no single one can be deemed authoritative. ${ }^{18}$ Our study uses the 2018 AKS data set. While this article was in preparation, an updated version was made available in 2019. However, we developed our network model using the 2018 version. The advantage of the AKS edition is the addition of a universal content identifier (UCI) that makes it possible to disambiguate historical figures with the same surname and given name. While the current UCI system may still contain some minor errors, researchers such as Lee Jaeok personally re-

Papers on Korea 1 (April 1974): 1-8; Han Yŏngu, Kwagŏ.

17 Wagner 1974, 2-3; Edward W. Wagner, "The Korean Chokpo as a Historical Source," Studies in Asian Genealogy (Brigham Young University Press, 1969), 141-152; Song June-ho, "The Government Examination Rosters of the Yi Dynasty," 153-176; Song Man-o, "The Wagner-Song Munkwa Project," 207.

18 Lee's dissertation has been published as a book. See Lee Jaeok [Yi Chaeok], Chosŏn sidae kwagŏ hapkyŏkcha ŭi tijit'ŏl ak'aibŭ wa inchŏk kwan'gyemang (P'aju: Pogosa, 2018). 
viewed all 15,151 records in the database with extreme care. ${ }^{19}$ We conclude that any inaccuracies in the 2018 AKS edition are negligible for our network modeling purposes.

\section{Methodology}

The creation of our model begins with converting the 2018 AKS Lee Jaeok Munkwa database into directed family networks of individuals. In our data set, we represent only successful munkwa candidates as nodes and drop any references to kin who failed to pass the examinations. If a candidate's father, grandfather, or great-grandfather is also a munkwa holder, we add a directed link between the candidate and his patrilineal ancestor. After multiple iterations, we are then able to track our data backward and identify the candidate's descendants as well.

Each node/individual is assigned scores. The first is the "upward score," which we define as the node's outdegree centrality. The more degree-holding immediate ancestors a node has, the larger the upward score. A node with a high upward score suggests that the person was likely born into a prestigious yangban family. Each node can have an outdegree centrality score of up to four, from the degree-holding father, grandfather, great-grandfather, and maternal grandfather, from the kinship information recorded in the Munkwa database (see Figure 1). One exception we introduce to this rule lies in excluding the record regarding the node's biological father. In Chosón society, adoption was a common strategy for ensuring the preservation of a yangban family's status and wealth. ${ }^{20}$ Since the node's stepfather was his legal father, from whom he would inherit the family's legacy, we have not included biological fathers in our calculations.

19 The discrepancy between the total number of records and the number of degree holders $(15,151$ vs. approximately 14,600$)$ is due to the fact that some candidates took and passed the civil service exam multiple times.

20 Pak Kyŏng, Chosŏn chŏn'gi ibyang kwa kajok chedo (Seoul: Hyean, 2011). 


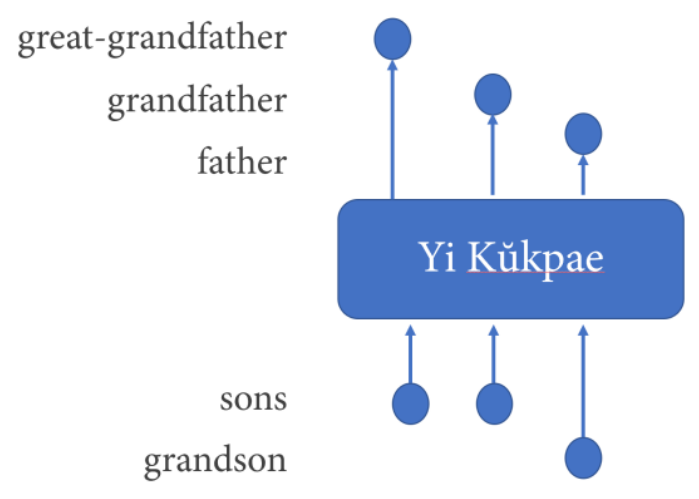

Fig. 1. A sample visualization of the node Yi Kŭkpae 李克培 (1422-1495) and directed edges to his kin.

The downward score is defined in a similar way. Unlike outdegree centrality, the indegree centrality score can exceed four, because multiple sons and grandsons may have passed the exams. However, we have limited this score to a maximum of four. For example, if a node has two sons and one maternal grandson who pass the exams, the downward score is given as two even though the indegree centrality score is three. The example of Yi Kŭkpae 李克培 (1422-1495) in Figure 1 will serve to explain this. Here, Yi Kŭkpae has an upward score of three, from his degree-holding great-grandfather, grandfather, and father, and a downward score of two, from his sons and grandson. The downward score is not the total sum of indegree centrality because it considers only the type of descendants, rather than the absolute number of descendants with a munkwa degree. The downward score is defined in this way for two reasons. First, we follow Lee Sangkuk and Park Jong Hee's argument that it was more important for a family to have at least one civil exam passer among its offspring than to have as many as possible. ${ }^{21}$ The gulf between the perceived social status of families with one degree-holder rather than none was vast, whereas the gap between those with two degree-holding off- 
spring rather than three was comparatively minor. Second, limiting the downward score to four makes our analysis more convenient and easier to interpret. Given the symmetry of the minimum and maximum upward and downward scores, we can assess whether a node has climbed up the ladder toward the elite or yangban society or has fallen away from that group. This allows us to construct the transition matrices shown in Table 2.

To demonstrate how this process works with specific examples, Table 1 shows the series of extreme cases in terms of the two scores. The first are those who may be called "grand slammers": people whose ancestors and descendants of all four types passed the munkwa exams. Of the approximately 14,600 degree holders in the database, there are eight such individuals. The second are those who may have achieved the greatest degree of upward change (dubbed "rags to riches"): none of their ancestors attained a munkwa degree, but all four types of their descendants did. Eleven such cases exist.

Using a node's upward and downward scores, we can characterize him as a "snake" or a "ladder." If a node's downward score is higher than his upward score, it suggests that the person has strengthened his clan's social status by enabling his descendants to pass the exams with relatively few resources inherited from his ancestors. As a result, he is considered a ladder. In contrast, if a node's downward score is lower than its upward score, it suggests that he received abundant social resources from preceding generations but failed to pass his status on to his descendants, so he is considered a snake.

We also examine the score in time-series. The available information on time in our data is the year in which each candidate passed the examination. We divide the dynasty into periods of 18 years in order to examine how the tendency changed over time. Because the regular civil examinations (singnyŏnsi 式年試) were held triennially, we set the length of each

21 Lee Sangkuk [MR: Yi Sangguk] and Jong Hee Park, "Quality over Quantity: A Lineage-Survival Strategy of Elite Families in Premodern Korea," Social Science History 43, no.1 (Spring 2019): 31-61. 
Table 1. Munkwa degree holders representing the extreme ends of upward and downward scores in our model.

\begin{tabular}{|c|c|c|c|c|c|}
\hline $\begin{array}{l}\text { Type of } \\
\text { Extreme } \\
\text { Case }\end{array}$ & Name & $\begin{array}{c}\text { Up- } \\
\text { ward } \\
\text { Score } \\
\end{array}$ & $\begin{array}{l}\text { Down } \\
\text { ward } \\
\text { Score } \\
\end{array}$ & $\begin{array}{l}\text { Cen- } \\
\text { trality }\end{array}$ & $\begin{array}{l}\text { Exam } \\
\text { Year }\end{array}$ \\
\hline \multirow{8}{*}{$\begin{array}{c}\text { Grand } \\
\text { Slammers }\end{array}$} & Chŏng Yunbok 丁胤福 & 4 & 4 & 11 & 1567 \\
\hline & Nam Isin 南以信 & 4 & 4 & 10 & 1590 \\
\hline & Nam Tuch'ŏm 南斗瞻 & 4 & 4 & 13 & 1616 \\
\hline & Yi Chigoeng 李志宏 & 4 & 4 & 8 & 1618 \\
\hline & Yun Kye 尹堦 & 4 & 4 & 11 & 1662 \\
\hline & Min Chinwŏn 閔鎭遠 & 4 & 4 & 13 & 1691 \\
\hline & Kim Chaero 金在魯 & 4 & 4 & 10 & 1710 \\
\hline & Min Myŏnghyŏk 閔命爀 & 4 & 4 & 8 & 1795 \\
\hline \multirow{11}{*}{$\begin{array}{l}\text { Rags to } \\
\text { Riches }\end{array}$} & Cho Sangch’i 曺劣治 & 0 & 4 & 7 & 1419 \\
\hline & Ki Ch'an 奇禶 & 0 & 4 & 6 & 1474 \\
\hline & Pak Chonyŏn 朴兆年 & 0 & 4 & 10 & 1489 \\
\hline & Hong Ip'yŏng 洪以平 & 0 & 4 & 11 & 1513 \\
\hline & Hwang Sau 黄士祐 & 0 & 4 & 5 & 1514 \\
\hline & Im Yŏl 任說 & 0 & 4 & 8 & 1533 \\
\hline & Yi Ryang 李樑 & 0 & 4 & 5 & 1552 \\
\hline & Hong Isang 洪履祥 & 0 & 4 & 18 & 1579 \\
\hline & O Paengyŏng 吳百齡 & 0 & 4 & 8 & 1594 \\
\hline & Sin Tǔkhong 22 申得洪 & 0 & 4 & 5 & 1639 \\
\hline & Yi Tŭgil 李得一 & 0 & 4 & 5 & 1763 \\
\hline
\end{tabular}

period as a multiple of three. The number 18 was chosen because we consider 18 years to be the shortest interval that would effectively prevent overlapping between generations. Using these data subgroupings, we can visualize how the three metrics changed over time: the ratio of ladders to

22 Sin Tŭkhong is a false detection due to an error in the 2018 AKS data set. His father, Sin Yong 申涌 (b. 1561), is a munkwa degree holder who passed the exam in 1591. The error may have been caused by his name change from Sin Sŏl 申渫 to Sin Yong and has been corrected in the official Academy of Korean Studies database. For the most up-to-date record, see: http://people.aks.ac.kr/front/dirSe r/exm/exmView.aks?exmId=EXM_MN_6JOb_1591_004382 
snakes, the proportion of suspected first-generation munkwa graduates in their family branches, and the relative number of steady performers who acted neither as snakes nor as ladders.

\section{Results}

Our model summarizes the upward and downward scores of all munkwa nodes in a five-by-five matrix. This matrix aggregates the total number of snakes and ladders for the entire Chosŏn dynasty and at 18-year intervals (see Table 2). The high proportion of ladders suggests that Chosŏn society a given period allowed some degree of social mobility, while a high proportion of snakes implies widespread intergenerational decline. In Table 2, ladders (1,211 nodes) are listed in the upper-right triangle, and snakes (5,771 nodes) are listed in the lower-left triangle. This indicates that a significant number of families whose patrilineal ancestors attained munkwa degrees failed to repeat the achievement and thus risked losing their prestige.

Matrices representing specific historical conjunctures require normalization. While the regular munkwa exam was held triennially, irregular examinations to commemorate special occasions were held during intervening years. Also, the number of conferred degrees soared in the nineteenth century. To account for this uneven distribution, our model takes the difference between the total number of ladders (the sum of cells in the matrix's upper-right triangle) and the total number of snakes (the sum of cells in the matrix's lower-left triangle) and divides it by the total number of degree holders in the given period (the sum of every component in the matrix). This normalization yields a value between -1 and 1 . A positive normalized score (between 0 and 1) indicates that the ladder effect is greater than the snake effect, while a negative normalized score (between -1 and 0 ) suggests the opposite. Put another way, if every node is a ladder - that is, if every descendant is more successful than his ancestorsthe normalized score in such a hypothetical case is 1 ; if every node is a 
snake - if every descendant is less successful than his ancestors - the normalized score in such a hypothetical case is -1 . The average normalized score for the entire Chosŏn dynasty is -0.30 .

To distinguish certain notable ladders from others, our model measures the proportion of those we call "pioneers" to the total. Pioneers are defined as nodes with an upward score of zero and a positive downward score; in the Table 2 matrices, they occupy the first row of the upper-right triangle. Figure 3, which divides the total number of pioneers by the sum of all ladders in the upper-right triangle, shows that the proportion of firstgeneration degree holders diminished over time. In the first two centuries

Table 2. Stochastic matrices of downward and upward scores. Ladders, marked in blue, are in the upper-right triangle; snakes, in red, are in the lower left triangle.

Entire dynasty

\begin{tabular}{c|c|c|c|c|c}
$\begin{array}{c}\text { Down- } \\
\text { ward } \\
\text { Upward }\end{array}$ & $\mathbf{0}$ & $\mathbf{1}$ & $\mathbf{2}$ & $\mathbf{3}$ & $\mathbf{4}$ \\
\hline $\mathbf{0}$ & 7,178 & 403 & 157 & 72 & 11 \\
\hline $\mathbf{1}$ & $\mathbf{2 , 6 0 1}$ & 678 & 278 & 126 & 19 \\
\hline $\mathbf{2}$ & $\mathbf{1 , 3 1 8}$ & $\mathbf{5 2 4}$ & 222 & 101 & 22 \\
\hline $\mathbf{3}$ & $\mathbf{5 5 2}$ & $\mathbf{2 8 4}$ & $\mathbf{1 4 0}$ & 83 & 22 \\
\hline $\mathbf{4}$ & $\mathbf{1 7 0}$ & $\mathbf{1 0 2}$ & $\mathbf{5 2}$ & $\mathbf{2 8}$ & 8 \\
\hline
\end{tabular}

1393-1410

\begin{tabular}{c|c|c|c|c|c}
$\begin{array}{c}\text { Down- } \\
\text { ward } \\
\text { Upward }\end{array}$ & $\mathbf{0}$ & $\mathbf{1}$ & $\mathbf{2}$ & $\mathbf{3}$ & $\mathbf{4}$ \\
\hline $\mathbf{0}$ & 166 & 13 & 9 & 4 & 0 \\
\hline $\mathbf{1}$ & $\mathbf{2 4}$ & 8 & 5 & 0 & 0 \\
\hline $\mathbf{2}$ & $\mathbf{4}$ & $\mathbf{1}$ & 3 & $\mathbf{0}$ & 1 \\
\hline $\mathbf{3}$ & $\mathbf{1}$ & $\mathbf{2}$ & $\mathbf{0}$ & 0 & 0 \\
\hline $\mathbf{4}$ & $\mathbf{0}$ & $\mathbf{0}$ & $\mathbf{0}$ & $\mathbf{0}$ & 0 \\
\hline
\end{tabular}


1411-1428

\begin{tabular}{c|c|c|c|c|c}
$\begin{array}{c}\text { Down- } \\
\text { ward }\end{array}$ & $\mathbf{0}$ & $\mathbf{1}$ & $\mathbf{2}$ & $\mathbf{3}$ & $\mathbf{4}$ \\
\hline $\mathbf{0}$ & 209 & $\mathbf{1 6}$ & $\mathbf{1 0}$ & 3 & $\mathbf{1}$ \\
\hline $\mathbf{1}$ & $\mathbf{2 2}$ & 13 & 5 & 3 & $\mathbf{0}$ \\
\hline $\mathbf{2}$ & $\mathbf{8}$ & $\mathbf{3}$ & 2 & 1 & 2 \\
\hline $\mathbf{3}$ & $\mathbf{0}$ & $\mathbf{0}$ & $\mathbf{1}$ & 1 & $\mathbf{0}$ \\
\hline $\mathbf{4}$ & $\mathbf{0}$ & $\mathbf{2}$ & $\mathbf{0}$ & $\mathbf{1}$ & 0 \\
\hline
\end{tabular}

1429-1446

\begin{tabular}{c|c|c|c|c|c}
\hline $\begin{array}{r}\text { Down- } \\
\text { ward }\end{array}$ & $\mathbf{0}$ & $\mathbf{1}$ & $\mathbf{2}$ & $\mathbf{3}$ & $\mathbf{4}$ \\
\hline $\mathbf{0}$ & 150 & 17 & 5 & 4 & 0 \\
\hline $\mathbf{1}$ & $\mathbf{2 6}$ & 14 & 7 & 3 & 0 \\
\hline $\mathbf{2}$ & $\mathbf{1 6}$ & $\mathbf{7}$ & 6 & 3 & 0 \\
\hline $\mathbf{3}$ & $\mathbf{4}$ & $\mathbf{1}$ & $\mathbf{0}$ & 3 & 0 \\
\hline $\mathbf{4}$ & $\mathbf{1}$ & $\mathbf{1}$ & $\mathbf{0}$ & $\mathbf{0}$ & 0 \\
\hline
\end{tabular}

1447-1464

\begin{tabular}{c|c|c|c|c|c}
\hline $\begin{array}{r}\text { Down- } \\
\text { ward }\end{array}$ & $\mathbf{0}$ & $\mathbf{1}$ & $\mathbf{2}$ & $\mathbf{3}$ & $\mathbf{4}$ \\
\hline $\mathbf{0}$ & 253 & 22 & $\mathbf{1 2}$ & 5 & $\mathbf{0}$ \\
\hline $\mathbf{1}$ & $\mathbf{7 3}$ & 21 & $\mathbf{1 6}$ & 5 & $\mathbf{0}$ \\
\hline $\mathbf{2}$ & $\mathbf{2 5}$ & $\mathbf{1 0}$ & 3 & 4 & $\mathbf{0}$ \\
\hline $\mathbf{3}$ & $\mathbf{1 1}$ & $\mathbf{8}$ & $\mathbf{5}$ & 2 & 2 \\
\hline $\mathbf{4}$ & $\mathbf{1}$ & $\mathbf{0}$ & $\mathbf{1}$ & $\mathbf{0}$ & 0 \\
\hline
\end{tabular}


1465-1482

\begin{tabular}{c|c|c|c|c|c}
$\begin{array}{c}\text { Down- } \\
\text { ward }\end{array}$ & $\mathbf{0}$ & $\mathbf{1}$ & $\mathbf{2}$ & $\mathbf{3}$ & $\mathbf{4}$ \\
\hline $\mathbf{0}$ & 251 & 16 & 9 & 6 & 1 \\
\hline $\mathbf{1}$ & $\mathbf{7 7}$ & 24 & 9 & 5 & 3 \\
\hline $\mathbf{2}$ & $\mathbf{2 8}$ & $\mathbf{1 1}$ & 7 & 2 & 0 \\
\hline $\mathbf{3}$ & $\mathbf{9}$ & $\mathbf{4}$ & $\mathbf{3}$ & 1 & 1 \\
\hline $\mathbf{4}$ & $\mathbf{0}$ & $\mathbf{0}$ & $\mathbf{2}$ & $\mathbf{0}$ & 0 \\
\hline
\end{tabular}

1483-1500

\begin{tabular}{c|c|c|c|c|c}
$\begin{array}{c}\text { Down- } \\
\text { ward } \\
\text { Upward }\end{array}$ & $\mathbf{0}$ & $\mathbf{1}$ & $\mathbf{2}$ & $\mathbf{3}$ & $\mathbf{4}$ \\
\hline $\mathbf{0}$ & 143 & 18 & 3 & 5 & 1 \\
\hline $\mathbf{1}$ & $\mathbf{7 9}$ & 20 & 10 & 3 & 0 \\
\hline $\mathbf{2}$ & $\mathbf{2 4}$ & $\mathbf{1 0}$ & 3 & 4 & 1 \\
\hline $\mathbf{3}$ & $\mathbf{1 1}$ & $\mathbf{4}$ & $\mathbf{2}$ & 1 & 1 \\
\hline $\mathbf{4}$ & $\mathbf{0}$ & $\mathbf{1}$ & $\mathbf{1}$ & $\mathbf{0}$ & 0 \\
\hline
\end{tabular}

1501-1518

\begin{tabular}{c|c|c|c|c|c}
$\begin{array}{c}\text { Down- } \\
\text { ward } \\
\text { Upward }\end{array}$ & $\mathbf{0}$ & $\mathbf{1}$ & $\mathbf{2}$ & $\mathbf{3}$ & $\mathbf{4}$ \\
\hline $\mathbf{0}$ & 179 & 38 & 8 & 4 & 2 \\
\hline $\mathbf{1}$ & $\mathbf{7 8}$ & 32 & 17 & 4 & 3 \\
\hline $\mathbf{2}$ & $\mathbf{2 9}$ & $\mathbf{1 3}$ & 10 & 0 & 0 \\
\hline $\mathbf{3}$ & $\mathbf{1 1}$ & $\mathbf{5}$ & $\mathbf{4}$ & 2 & 1 \\
\hline $\mathbf{4}$ & $\mathbf{0}$ & $\mathbf{0}$ & $\mathbf{0}$ & $\mathbf{1}$ & 0 \\
\hline
\end{tabular}


1519-1536

\begin{tabular}{c|c|c|c|c|c}
$\begin{array}{r}\text { Down- } \\
\text { ward } \\
\text { Upward }\end{array}$ & $\mathbf{0}$ & $\mathbf{1}$ & $\mathbf{2}$ & $\mathbf{3}$ & $\mathbf{4}$ \\
\hline $\mathbf{0}$ & 167 & 27 & 11 & 9 & 1 \\
\hline $\mathbf{1}$ & $\mathbf{7 4}$ & 23 & 13 & 6 & 0 \\
\hline $\mathbf{2}$ & $\mathbf{3 8}$ & $\mathbf{1 5}$ & 4 & 5 & 0 \\
\hline $\mathbf{3}$ & $\mathbf{1 2}$ & $\mathbf{5}$ & $\mathbf{3}$ & 2 & 2 \\
\hline $\mathbf{4}$ & $\mathbf{1}$ & $\mathbf{1}$ & $\mathbf{0}$ & $\mathbf{0}$ & 0 \\
\hline
\end{tabular}

1537-1554

\begin{tabular}{c|c|c|c|c|c}
$\begin{array}{c}\text { Down- } \\
\text { ward } \\
\text { Upward }\end{array}$ & $\mathbf{0}$ & $\mathbf{1}$ & $\mathbf{2}$ & $\mathbf{3}$ & $\mathbf{4}$ \\
\hline $\mathbf{0}$ & 166 & $\mathbf{1 9}$ & 9 & 4 & 1 \\
\hline $\mathbf{1}$ & $\mathbf{8 0}$ & 29 & $\mathbf{1 4}$ & 4 & 1 \\
\hline $\mathbf{2}$ & $\mathbf{3 2}$ & $\mathbf{2 1}$ & 9 & 8 & 2 \\
\hline $\mathbf{3}$ & $\mathbf{1 0}$ & $\mathbf{6}$ & $\mathbf{7}$ & 4 & $\mathbf{0}$ \\
\hline $\mathbf{4}$ & $\mathbf{0}$ & $\mathbf{2}$ & $\mathbf{1}$ & $\mathbf{1}$ & 0 \\
\hline
\end{tabular}

1555-1572

\begin{tabular}{c|c|c|c|c|c}
$\begin{array}{r}\text { Down- } \\
\text { ward }\end{array}$ & $\mathbf{0}$ & $\mathbf{1}$ & $\mathbf{2}$ & $\mathbf{3}$ & $\mathbf{4}$ \\
\hline $\mathbf{0}$ & 137 & 29 & 8 & 3 & 0 \\
\hline $\mathbf{1}$ & $\mathbf{8 5}$ & 36 & $\mathbf{1 3}$ & 8 & 0 \\
\hline $\mathbf{2}$ & $\mathbf{4 5}$ & $\mathbf{2 2}$ & 14 & 4 & 2 \\
\hline $\mathbf{3}$ & $\mathbf{1 2}$ & $\mathbf{5}$ & $\mathbf{6}$ & 6 & 0 \\
\hline $\mathbf{4}$ & $\mathbf{4}$ & $\mathbf{6}$ & $\mathbf{1}$ & $\mathbf{0}$ & 1 \\
\hline
\end{tabular}


1573-1590

\begin{tabular}{c|c|c|c|c|c}
$\begin{array}{c}\text { Down- } \\
\text { ward }\end{array}$ & $\mathbf{0}$ & $\mathbf{1}$ & $\mathbf{2}$ & $\mathbf{3}$ & $\mathbf{4}$ \\
\hline $\mathbf{0}$ & 178 & 22 & 9 & 5 & 1 \\
\hline $\mathbf{1}$ & $\mathbf{9 4}$ & 29 & 22 & 16 & 2 \\
\hline $\mathbf{2}$ & 44 & $\mathbf{2 6}$ & 11 & 8 & 2 \\
\hline $\mathbf{3}$ & $\mathbf{1 8}$ & $\mathbf{6}$ & $\mathbf{3}$ & 8 & 2 \\
\hline $\mathbf{4}$ & $\mathbf{3}$ & $\mathbf{6}$ & $\mathbf{1}$ & $\mathbf{0}$ & 1 \\
\hline
\end{tabular}

1591-1608

\begin{tabular}{c|c|c|c|c|c}
$\begin{array}{c}\text { Down- } \\
\text { ward } \\
\text { Upward }\end{array}$ & $\mathbf{0}$ & $\mathbf{1}$ & $\mathbf{2}$ & $\mathbf{3}$ & $\mathbf{4}$ \\
\hline $\mathbf{0}$ & 143 & 19 & 12 & 4 & 1 \\
\hline $\mathbf{1}$ & $\mathbf{7 9}$ & 30 & 18 & 8 & 2 \\
\hline $\mathbf{2}$ & $\mathbf{3 9}$ & $\mathbf{2 1}$ & 16 & 10 & 1 \\
\hline $\mathbf{3}$ & $\mathbf{1 5}$ & $\mathbf{1 5}$ & $\mathbf{8}$ & 3 & 0 \\
\hline $\mathbf{4}$ & $\mathbf{7}$ & $\mathbf{6}$ & $\mathbf{3}$ & $\mathbf{2}$ & 0 \\
\hline
\end{tabular}

1609-1626

\begin{tabular}{c|c|c|c|c|c}
$\begin{array}{c}\text { Down- } \\
\text { ward }\end{array}$ & $\mathbf{0}$ & $\mathbf{1}$ & $\mathbf{2}$ & $\mathbf{3}$ & $\mathbf{4}$ \\
\hline $\mathbf{0}$ & 217 & 17 & 12 & 0 & 0 \\
\hline $\mathbf{1}$ & $\mathbf{1 3 5}$ & 34 & 10 & 8 & 6 \\
\hline $\mathbf{2}$ & $\mathbf{8 1}$ & $\mathbf{3 4}$ & 12 & 9 & 2 \\
\hline $\mathbf{3}$ & $\mathbf{3 6}$ & $\mathbf{1 2}$ & $\mathbf{8}$ & 5 & 2 \\
\hline $\mathbf{4}$ & $\mathbf{7}$ & $\mathbf{4}$ & $\mathbf{3}$ & $\mathbf{2}$ & 2 \\
\hline
\end{tabular}


1627-1644

\begin{tabular}{c|c|c|c|c|c}
\hline $\begin{array}{c}\text { Down- } \\
\text { ward }\end{array}$ & $\mathbf{0}$ & $\mathbf{1}$ & $\mathbf{2}$ & $\mathbf{3}$ & $\mathbf{4}$ \\
\hline $\mathbf{0}$ & 148 & 21 & 7 & 4 & 1 \\
\hline $\mathbf{1}$ & $\mathbf{8 3}$ & 30 & 10 & 6 & 0 \\
\hline $\mathbf{2}$ & $\mathbf{5 8}$ & $\mathbf{2 8}$ & 14 & 7 & 0 \\
\hline $\mathbf{3}$ & $\mathbf{2 5}$ & $\mathbf{7}$ & $\mathbf{1 1}$ & 7 & 2 \\
\hline $\mathbf{4}$ & $\mathbf{9}$ & $\mathbf{6}$ & $\mathbf{0}$ & $\mathbf{2}$ & 0 \\
\hline
\end{tabular}

1645-1662

\begin{tabular}{c|c|c|c|c|c}
$\begin{array}{c}\text { Down- } \\
\text { ward } \\
\text { Upward }\end{array}$ & $\mathbf{0}$ & $\mathbf{1}$ & $\mathbf{2}$ & $\mathbf{3}$ & $\mathbf{4}$ \\
\hline $\mathbf{0}$ & 160 & $\mathbf{1 5}$ & 4 & 2 & 0 \\
\hline $\mathbf{1}$ & $\mathbf{7 3}$ & 13 & 18 & 6 & 1 \\
\hline $\mathbf{2}$ & $\mathbf{7 2}$ & $\mathbf{1 7}$ & 14 & 2 & 0 \\
\hline $\mathbf{3}$ & $\mathbf{2 4}$ & $\mathbf{2 2}$ & $\mathbf{1 7}$ & 5 & 4 \\
\hline $\mathbf{4}$ & $\mathbf{1 2}$ & $\mathbf{9}$ & $\mathbf{5}$ & $\mathbf{1}$ & 1 \\
\hline
\end{tabular}

1663-1680

\begin{tabular}{c|c|c|c|c|c}
$\begin{array}{c}\text { Down- } \\
\text { ward }\end{array}$ & $\mathbf{0}$ & $\mathbf{1}$ & $\mathbf{2}$ & $\mathbf{3}$ & $\mathbf{4}$ \\
\hline $\mathbf{0}$ & 194 & $\mathbf{1 4}$ & 7 & 3 & 0 \\
\hline $\mathbf{1}$ & $\mathbf{6 8}$ & 22 & 7 & 7 & 1 \\
\hline $\mathbf{2}$ & $\mathbf{3 9}$ & $\mathbf{2 8}$ & 14 & 2 & 0 \\
\hline $\mathbf{3}$ & $\mathbf{3 3}$ & $\mathbf{1 7}$ & $\mathbf{1 0}$ & 7 & 0 \\
\hline $\mathbf{4}$ & $\mathbf{2 0}$ & $\mathbf{7}$ & $\mathbf{3}$ & $\mathbf{2}$ & 0 \\
\hline
\end{tabular}


1681-1698

\begin{tabular}{c|c|c|c|c|c}
$\begin{array}{c}\text { Down- } \\
\text { ward }\end{array}$ & $\mathbf{0}$ & $\mathbf{1}$ & $\mathbf{2}$ & $\mathbf{3}$ & $\mathbf{4}$ \\
\hline $\mathbf{0}$ & 204 & 20 & 3 & 1 & 0 \\
\hline $\mathbf{1}$ & $\mathbf{8 2}$ & 32 & 11 & 7 & 1 \\
\hline $\mathbf{2}$ & $\mathbf{5 8}$ & $\mathbf{2 9}$ & 9 & 3 & 1 \\
\hline $\mathbf{3}$ & $\mathbf{3 9}$ & $\mathbf{2 3}$ & $\mathbf{1 0}$ & 5 & 3 \\
\hline $\mathbf{4}$ & $\mathbf{1 7}$ & $\mathbf{7}$ & $\mathbf{4}$ & $\mathbf{5}$ & 1 \\
\hline
\end{tabular}

1699-1716

\begin{tabular}{c|c|c|c|c|c}
$\begin{array}{c}\text { Down- } \\
\text { ward } \\
\text { Upward }\end{array}$ & $\mathbf{0}$ & $\mathbf{1}$ & $\mathbf{2}$ & $\mathbf{3}$ & $\mathbf{4}$ \\
\hline $\mathbf{0}$ & 218 & 16 & 3 & 0 & 0 \\
\hline $\mathbf{1}$ & $\mathbf{8 1}$ & 19 & 8 & 5 & 0 \\
\hline $\mathbf{2}$ & $\mathbf{7 6}$ & $\mathbf{2 5}$ & 13 & 4 & 1 \\
\hline $\mathbf{3}$ & $\mathbf{2 8}$ & $\mathbf{1 5}$ & $\mathbf{9}$ & 2 & 0 \\
\hline $\mathbf{4}$ & $\mathbf{6}$ & $\mathbf{3}$ & $\mathbf{2}$ & $\mathbf{2}$ & 1 \\
\hline
\end{tabular}

1717-1734

\begin{tabular}{c|c|c|c|c|c}
$\begin{array}{c}\text { Down- } \\
\text { ward }\end{array}$ & $\mathbf{0}$ & $\mathbf{1}$ & $\mathbf{2}$ & $\mathbf{3}$ & $\mathbf{4}$ \\
\hline $\mathbf{0}$ & 267 & 7 & 2 & 3 & 0 \\
\hline $\mathbf{1}$ & $\mathbf{1 2 3}$ & 40 & 15 & 5 & 0 \\
\hline $\mathbf{2}$ & $\mathbf{6 5}$ & $\mathbf{3 4}$ & 10 & 5 & 2 \\
\hline $\mathbf{3}$ & $\mathbf{3 3}$ & $\mathbf{2 6}$ & $\mathbf{8}$ & 2 & 0 \\
\hline $\mathbf{4}$ & $\mathbf{9}$ & $\mathbf{6}$ & $\mathbf{5}$ & $\mathbf{2}$ & 0 \\
\hline
\end{tabular}


1735-1752

\begin{tabular}{c|c|c|c|c|c}
$\begin{array}{c}\text { Down- } \\
\text { ward }\end{array}$ & $\mathbf{0}$ & $\mathbf{1}$ & $\mathbf{2}$ & $\mathbf{3}$ & $\mathbf{4}$ \\
\hline $\mathbf{0}$ & 290 & 13 & 4 & 0 & 0 \\
\hline $\mathbf{1}$ & $\mathbf{1 1 8}$ & 40 & 9 & 3 & 0 \\
\hline $\mathbf{2}$ & $\mathbf{6 1}$ & $\mathbf{2 2}$ & 10 & 1 & 0 \\
\hline $\mathbf{3}$ & $\mathbf{1 6}$ & $\mathbf{1 8}$ & $\mathbf{5}$ & 7 & 0 \\
\hline $\mathbf{4}$ & $\mathbf{8}$ & $\mathbf{6}$ & $\mathbf{3}$ & $\mathbf{2}$ & 0 \\
\hline
\end{tabular}

1753-1770

\begin{tabular}{c|c|c|c|c|c}
$\begin{array}{c}\text { Down- } \\
\text { ward } \\
\text { Upward }\end{array}$ & $\mathbf{0}$ & $\mathbf{1}$ & $\mathbf{2}$ & $\mathbf{3}$ & $\mathbf{4}$ \\
\hline $\mathbf{0}$ & 361 & 8 & 3 & 2 & 1 \\
\hline $\mathbf{1}$ & $\mathbf{1 5 2}$ & 25 & 11 & 3 & 0 \\
\hline $\mathbf{2}$ & $\mathbf{8 8}$ & $\mathbf{1 9}$ & $\mathbf{7}$ & $\mathbf{6}$ & 1 \\
\hline $\mathbf{3}$ & $\mathbf{2 4}$ & $\mathbf{7}$ & $\mathbf{2}$ & 4 & 0 \\
\hline $\mathbf{4}$ & $\mathbf{1 3}$ & $\mathbf{5}$ & $\mathbf{5}$ & $\mathbf{0}$ & 0 \\
\hline
\end{tabular}

1771-1788

\begin{tabular}{c|c|c|c|c|c}
$\begin{array}{r}\text { Down- } \\
\text { ward }\end{array}$ & $\mathbf{0}$ & $\mathbf{1}$ & $\mathbf{2}$ & $\mathbf{3}$ & $\mathbf{4}$ \\
\hline $\mathbf{0}$ & 442 & 3 & 1 & 0 & 0 \\
\hline $\mathbf{1}$ & $\mathbf{1 3 6}$ & 30 & 10 & 3 & 0 \\
\hline $\mathbf{2}$ & $\mathbf{7 5}$ & $\mathbf{1 9}$ & 11 & 2 & 1 \\
\hline $\mathbf{3}$ & $\mathbf{3 4}$ & $\mathbf{1 5}$ & $\mathbf{1}$ & 2 & 2 \\
\hline $\mathbf{4}$ & $\mathbf{8}$ & $\mathbf{4}$ & $\mathbf{3}$ & $\mathbf{1}$ & 0 \\
\hline
\end{tabular}


1789-1806

\begin{tabular}{c|c|c|c|c|c}
$\begin{array}{c}\text { Down- } \\
\text { ward }\end{array}$ & $\mathbf{0}$ & $\mathbf{1}$ & $\mathbf{2}$ & $\mathbf{3}$ & $\mathbf{4}$ \\
\hline $\mathbf{0}$ & 365 & 5 & 3 & 1 & 0 \\
\hline $\mathbf{1}$ & $\mathbf{1 2 7}$ & 20 & 7 & 5 & 0 \\
\hline $\mathbf{2}$ & $\mathbf{6 6}$ & $\mathbf{2 2}$ & 6 & 5 & 2 \\
\hline $\mathbf{3}$ & $\mathbf{1 9}$ & $\mathbf{5}$ & $\mathbf{6}$ & 1 & 0 \\
\hline $\mathbf{4}$ & $\mathbf{2}$ & $\mathbf{2}$ & $\mathbf{4}$ & $\mathbf{1}$ & 1 \\
\hline
\end{tabular}

1807-1824

\begin{tabular}{c|c|c|c|c|c}
$\begin{array}{c}\text { Down- } \\
\text { ward }\end{array}$ & $\mathbf{0}$ & $\mathbf{1}$ & $\mathbf{2}$ & $\mathbf{3}$ & $\mathbf{4}$ \\
\hline $\mathbf{0}$ & 296 & 3 & 0 & 0 & 0 \\
\hline $\mathbf{1}$ & $\mathbf{7 4}$ & 18 & 7 & 1 & 0 \\
\hline $\mathbf{2}$ & $\mathbf{3 8}$ & $\mathbf{2 0}$ & 4 & 1 & 0 \\
\hline $\mathbf{3}$ & $\mathbf{1 2}$ & $\mathbf{8}$ & $\mathbf{8}$ & 2 & 0 \\
\hline $\mathbf{4}$ & $\mathbf{1}$ & $\mathbf{1}$ & $\mathbf{1}$ & $\mathbf{1}$ & 0 \\
\hline
\end{tabular}

1825-1842

\begin{tabular}{c|c|c|c|c|c}
$\begin{array}{c}\text { Down- } \\
\text { ward }\end{array}$ & $\mathbf{0}$ & $\mathbf{1}$ & $\mathbf{2}$ & $\mathbf{3}$ & $\mathbf{4}$ \\
\hline $\mathbf{0}$ & 289 & 1 & 1 & 0 & 0 \\
\hline $\mathbf{1}$ & $\mathbf{9 2}$ & 14 & 2 & 2 & 0 \\
\hline $\mathbf{2}$ & $\mathbf{4 4}$ & $\mathbf{2 0}$ & 7 & 0 & 0 \\
\hline $\mathbf{3}$ & $\mathbf{1 1}$ & $\mathbf{1 6}$ & $\mathbf{3}$ & 1 & 0 \\
\hline $\mathbf{4}$ & $\mathbf{8}$ & $\mathbf{5}$ & $\mathbf{3}$ & $\mathbf{2}$ & 0 \\
\hline
\end{tabular}


1843-1860

\begin{tabular}{c|c|c|c|c|c}
$\begin{array}{c}\text { Down- } \\
\text { ward } \\
\text { Upward }\end{array}$ & $\mathbf{0}$ & $\mathbf{1}$ & $\mathbf{2}$ & $\mathbf{3}$ & $\mathbf{4}$ \\
\hline $\mathbf{0}$ & 319 & 3 & 2 & 0 & 0 \\
\hline $\mathbf{1}$ & $\mathbf{1 0 4}$ & 34 & 3 & 0 & 0 \\
\hline $\mathbf{2}$ & $\mathbf{6 5}$ & $\mathbf{2 9}$ & 3 & 0 & 0 \\
\hline $\mathbf{3}$ & $\mathbf{3 6}$ & $\mathbf{2 2}$ & $\mathbf{0}$ & 0 & 0 \\
\hline $\mathbf{4}$ & $\mathbf{6}$ & 7 & $\mathbf{1}$ & $\mathbf{0}$ & 0 \\
\hline
\end{tabular}

1861-1878

\begin{tabular}{c|c|c|c|c|c}
$\begin{array}{c}\text { Down- } \\
\text { ward } \\
\text { Upward }\end{array}$ & $\mathbf{0}$ & $\mathbf{1}$ & $\mathbf{2}$ & $\mathbf{3}$ & $\mathbf{4}$ \\
\hline $\mathbf{0}$ & 448 & 0 & 0 & 0 & 0 \\
\hline $\mathbf{1}$ & 117 & 20 & 1 & 0 & 0 \\
\hline 2 & $\mathbf{6 1}$ & $\mathbf{1 6}$ & 0 & 0 & 0 \\
\hline 3 & 44 & 9 & 0 & 0 & 0 \\
\hline 4 & 11 & 5 & 0 & 0 & 0 \\
\hline
\end{tabular}

1879-1896

\begin{tabular}{c|c|c|c|c|c}
$\begin{array}{r}\text { Down- } \\
\text { ward }\end{array}$ & $\mathbf{0}$ & $\mathbf{1}$ & $\mathbf{2}$ & $\mathbf{3}$ & $\mathbf{4}$ \\
\hline $\mathbf{0}$ & 818 & 1 & 0 & 0 & 0 \\
\hline $\mathbf{1}$ & $\mathbf{2 4 5}$ & 8 & 0 & 0 & 0 \\
\hline $\mathbf{2}$ & $\mathbf{3 9}$ & $\mathbf{2}$ & 0 & 0 & 0 \\
\hline $\mathbf{3}$ & $\mathbf{2 4}$ & $\mathbf{1}$ & $\mathbf{0}$ & 0 & 0 \\
\hline $\mathbf{4}$ & $\mathbf{1 6}$ & $\mathbf{0}$ & $\mathbf{0}$ & $\mathbf{0}$ & 0 \\
\hline
\end{tabular}


of the Chosŏn dynasty, the vast majority of ladders were pioneers. That was no longer the case after the Imjin War of 1592 (see Figure 3).

Our analysis has produced some unexpected discoveries. The chances of a candidate from a non-elite family attaining the munkwa degree decreased over time (see Figure 3), even though the total number of conferred degrees increased (see Figure 4). This finding will not surprise historians of Korea. Our quantification of this historical change, however, should be of interest to Chosŏn specialists. Before the Imjin War, the normalized scores for our 18-year intervals lie in the upper left quadrant defined by the weighted average of -0.3 for the entire dynasty and up to the year 1592; after the Imjin War, remarkably, the data points fall within the lower right quadrant, below -0.3 . Our results demonstrate the extent to which candidates suspected of being commoners passed the munkwa in pre-1592 Chosŏn, as emphasized by Han Yŏngu and Yong-Ho Ch'oe, and the dominance of the yangban status quo already in the first half of the sixteenth dynasty, which Kim Ch'anghyŏn has shown with a thorough examination of early Chosŏn munkwa data. ${ }^{23}$ After the sixteenth-century ebb and the Imjin War, Chosŏn society never recovered to the weighted average normalized score for the entire dynasty (see Figure 2). Rather, candidates from families with a history of producing munkwa degree holders simply sought to match what their ancestors had achieved. The proportion of nodes who can be referred to as "sustained performers" declined continuously through the fifteenth and sixteenth centuries, hit its lowest point during the Imjin War, and then increased steadily in the seventeenth and eighteenth centuries (see Figure 5).

However, normalized and proportional scores lump together different types of snakes and ladders without giving due weight to a node's indegree centrality values. Take Hong Ip'yŏng 洪以平 (1463-1525), who passed the munkwa exams in 1513 at the age of fifty-one se 歲 and had

23 Han Yŏngu, Kwagŏ; Yong-Ho Ch'oe, “Commoners in Early Yi Dynasty”; Kim Ch'anghyŏn, Chosŏn ch'ogi munkwa kŭpcheja yŏn'gu (Seoul: Ilchogak, 1999). 


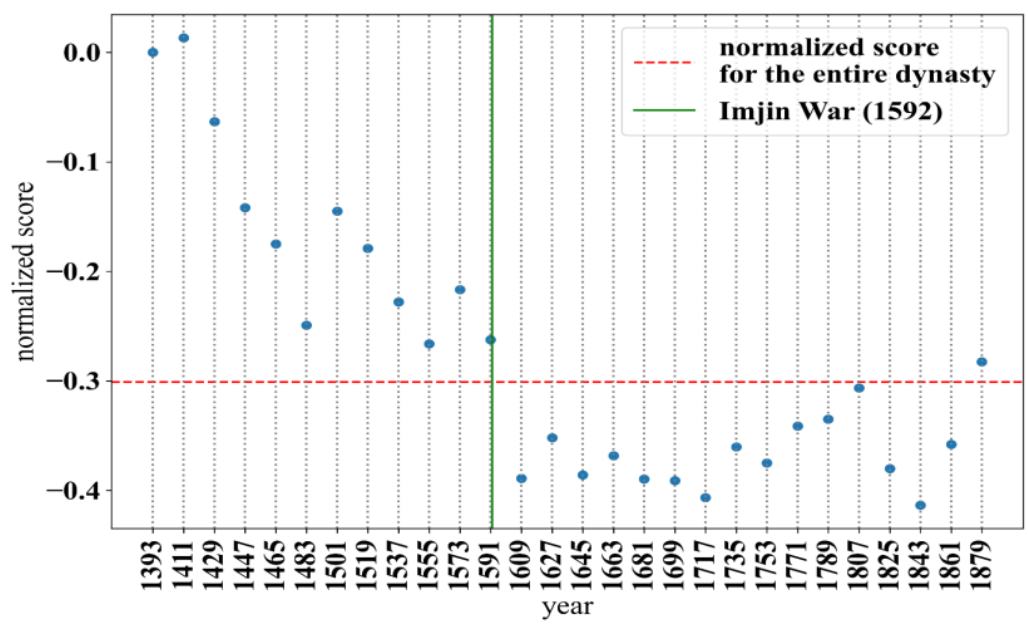

Fig. 2. Normalized score at 18-year intervals.

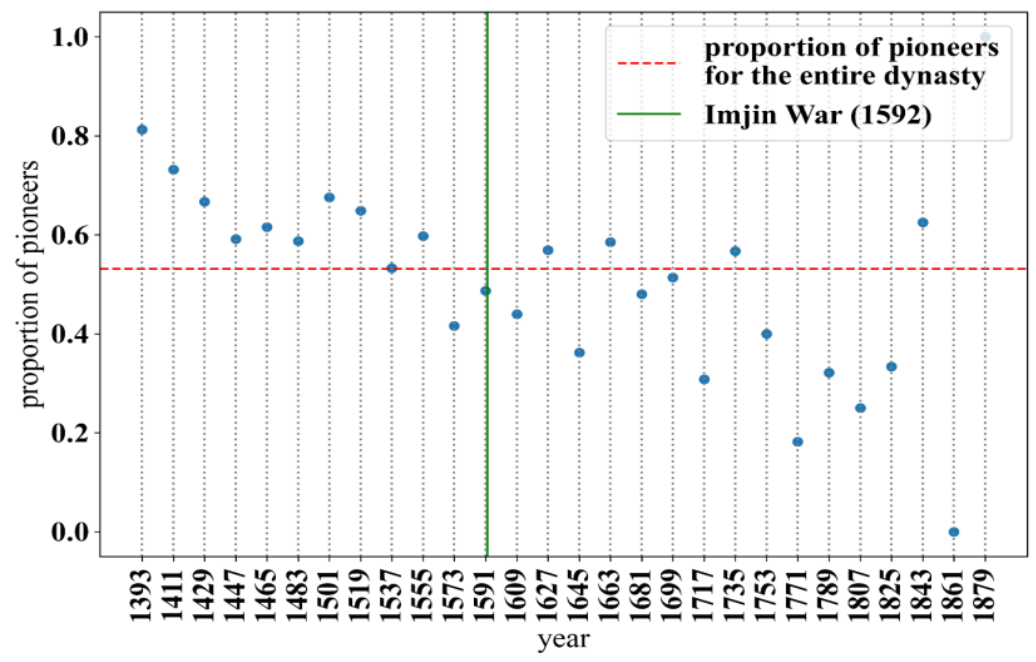

Fig. 3. Proportion of "pioneers" at 18-year intervals. 


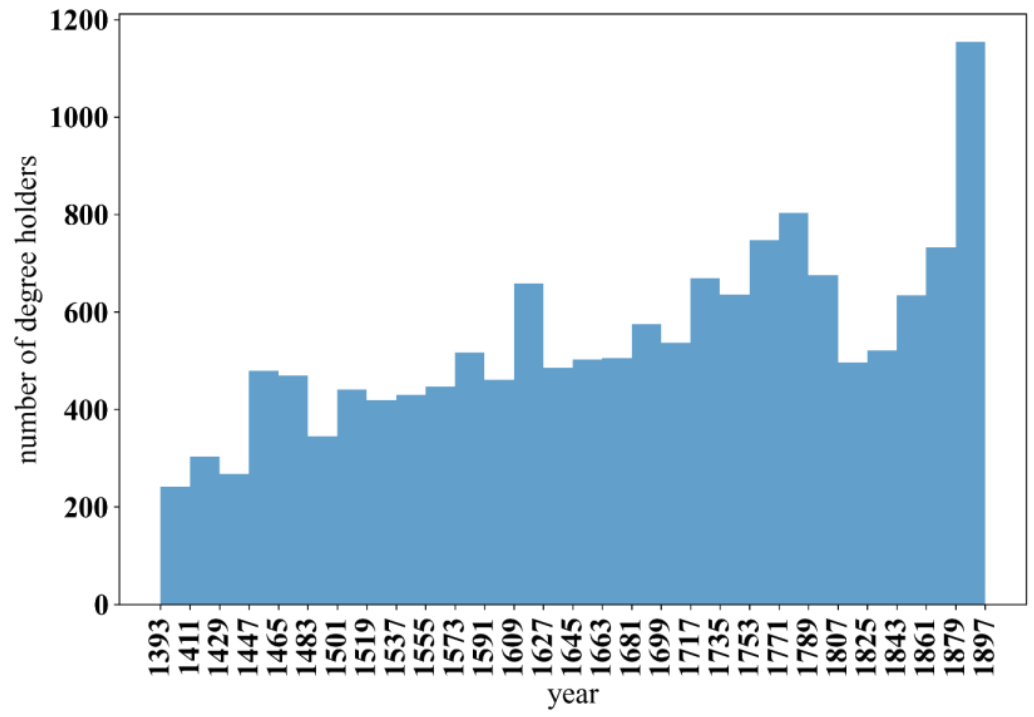

Fig. 4. Aggregate of conferred munkwa degrees at 18-year intervals.

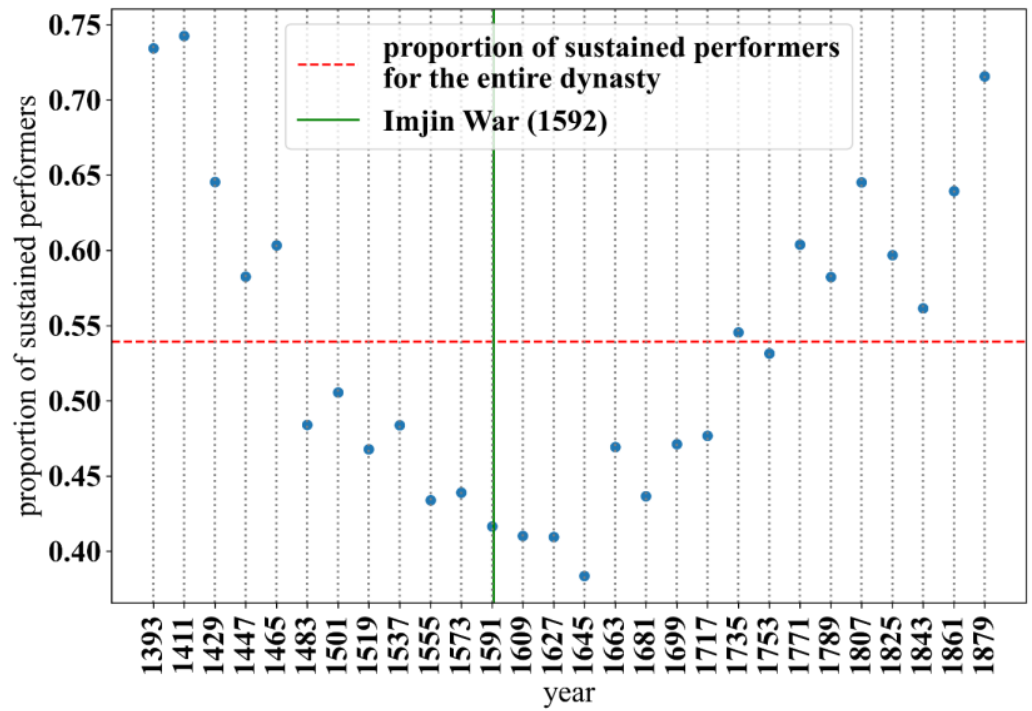

Fig. 5. Proportion of "sustained performers" at 18-year intervals. 
no ancestors within three generations who belonged to the civil service. ${ }^{24}$ Hong is one of eleven exceptional ladders, with an astonishing eleven sons, grandsons, great-grandsons, and maternal grandsons who also attained munkwa degrees. He is assigned our model's maximum downward score of four. Further, the process of calculating normalized scores does not distinguish Hong from 403 more "ordinary" ladders, each of whom produced just one munkwa degree-holder from among his sons, grandsons, great-grandsons, and maternal grandsons.

To address this shortcoming, we have also produced normalized histograms that consider the centrality values of each snake and ladder. This method enables much more granular insights into the rates at which munkwa candidates experienced downward social mobility. The histogram in Figure 6 summarizes the difference between each node's down-

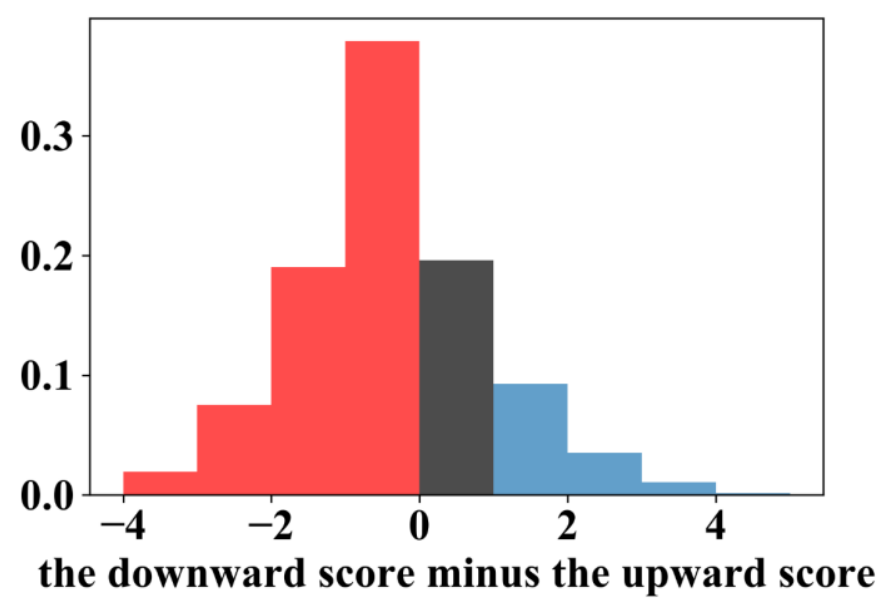

Fig. 6. Downward score minus upward score for the whole dynasty.

24 Nonetheless, Hong Ip'yŏng was not a man of common origins. His father was General Hong Kwisŏn 洪貴孫 (n.d.), a military official who ended his career at the senior third rank. No details are known about his paternal grandfather and great-grandfather. 


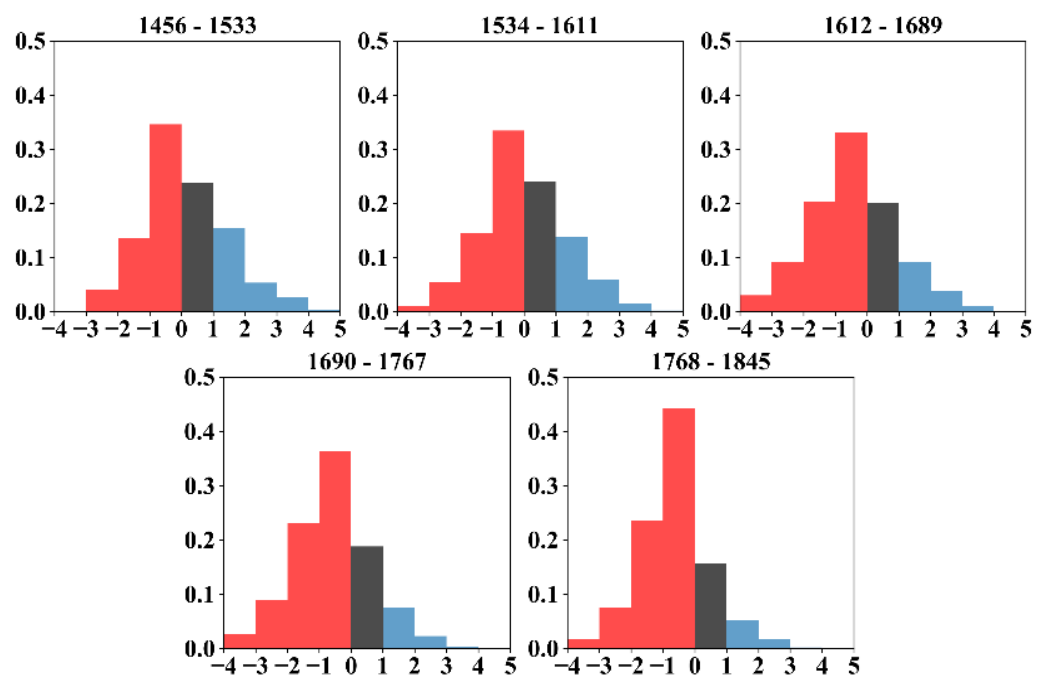

Fig. 7. Downward score minus upward score in 78 -year time slices.

ward and upward scores, with a range from -4 to 4 . The positive values in the horizontal axis, colored in blue, are ladders, and the negative ones in red are snakes. The black bars represent sustained performers. The histogram reveals a bell-shaped distribution with a slight rightward skew due to the smaller proportion of ladders. When we divide the data into histograms for 78-year time slices and juxtapose the results, we discover a steady rise of "ordinary" snakes with a score of -1 or -2 , and a corresponding decline in those at the extremities (see Figure 7). From a historical perspective, this change in munkwa data suggests that the decline in exam performance in the later Chosonn dynasty was at once consistent and gradual.

\section{Conclusion}

When Edward Wagner and Song June-ho began compiling the Munkwa database in the 1960s, they intended to study the power structure of 
the Chosŏn elite from a network perspective. Despite running into text encoding challenges and utilizing comparatively inefficient punch card systems, the aggregation of munkwa degrees by choronym and address was completed in less than five years. The Wagner-Song Munkwa Project received funding from the Ford Foundation in 1967; Edward Wagner presented his first data analysis at a conference of the Association for Asian Studies in 1971. What prolonged the Wagner-Song Munkwa Project into an endeavor that remained unfinished for more than thirty years was their ambition to include genealogical materials in the database. Today, with modern computing capacity and South Korea's impressive advances in the digitization of historical materials, we can attempt to do what Edward Wagner and Song June-ho wished to do in the 1960s.

Our network analysis of munkwa data connects and combines what appear to be disparate historical records to produce an enhanced understanding of Chosŏn society's internal dynamics and power structure. Historians of Korea are aware that the Imjin War of 1592 was cataclysmic, and that downward mobility was rampant in the seventeenth and eighteenth centuries. What has been lacking in the historiography is a quantitative way of measuring the rich kinship data that exists in Korean sources, which was why Wagner and Song wished to link the munkwa roster to genealogies. Our data-driven narrative has measured the degree to which Chosŏn's higher civil examination candidates reproduced their ancestors' exam performance or failed to do so. Our transition matrices, normalized scores, and histograms not only identify systemic changes over the course of the dynasty but also enable granular insights into the degree, rate, and direction of change in different periods.

Our work can be improved in at least two ways. First, a more complex quantification of "success" could be implemented. Although we assigned scores based on network centralities as a measure of success, classifying them into only five discrete groups has limitations. In Chosŏn society, the examination degree did not in itself confer status, wealth, and prestige; it was, rather, the gateway to the yangban positions in the central bureaucracy that made a yangban aristocrat a yangban. As a follow-up to this 
study, we plan to cleanse the approximately 350,000 official career records extracted from the Annals of the Chosŏn Dynasty (Chosŏn wangjo sillok 朝鮮王朝實錄) and to link this data to the munkwa data. Finally, further network analysis concerning marriage can be undertaken. In our research, we could only see the marginal effects of marriage, because the only information that was available about marriage concerns maternal grandfathers. By tracking fathers-in-law or actual marriage data in the pedigree of each node, we will be able to see the dynamics of elite marriage strategies in a more fundamental way.

\section{References}

1. Ch'oe, Yong-Ho, "Commoners in Early Yi Dynasty Civil Examinations: An Aspect of Korean Social Structure, 1392-1600." Journal of Asian Studies 33, no. 4 (1974): 611-631.

2. Cha, Javier. "Digital Korean Studies: Recent Advances and New Frontiers.” Digital Library Perspectives 34, no. 3 (2018): 227-244.

3. Cha, Javier. "To Build a Centralizing Regime: Yangban Aristocracy and Medieval Patrimonialism." Seoul Journal of Korean Studies 32, no. 1 (2019): 35-80.

4. Haboush, JaHyun Kim. "Constructing the Center: The Ritual Controversy and the Search for a New Identity." In Culture and the State in Late Chosŏn Korea, edited by JaHyun Kim Haboush and Martina Deuchler, 46-90. Cambridge: Harvard University Asia Center, 2002.

5. Haboush, JaHyun Kim. The Great East Asian War and the Birth of the Korean Nation. New York: Columbia University Press, 2016.

6. Han, Yŏngu. Kwagŏ: ch'ulse ŭi sadari. Chisik sanŏpsa, 2013.

7. Hŏ Hŭngsik. Koryŏ ŭi kwagŏ chedo. Ilchogak, 2005.

8. Hur, Nam-lin. "Works in English on the Imjin War and the Challenge of Research." International Journal of Korean History 18, no. 2 (2013): 53-80.

9. Kim, Sun Joo, “The Wagner-Song Munkwa Project and Its Legacy in 
the Research of Korean History." Unpublished. https://projects.iq.har vard.edu/files/gpks/files/sun_joo_kim_the_wagner-song_munkwa_pr oject_and_its_legacy_in_the_research_of_korean_history.pdf

10. Lee, Sangkuk and Jong Hee Park. "Quality over Quantity: A Lineage-Survival Strategy of Elite Families in Premodern Korea." Social Science History 43, no. 1 (2019): 31-61.

11. Miyajima Hiroshi. yangban: Uri ka mollat tŏn yangban ŭi silch'e rŭl ch'ajasŏ. Seoul: Nŏmŏ Puksŭ, 2014.

12. Pak, Hyŏnsun. 'Kukcho munkwa pangmok ŭi p'yŏnch'an kwa 18segi inmul chŏngbohak.” Kyujanggak 56 (2020): 173-215.

13. Pak, Kyŏng. Chosŏn chŏn'gi ibyang kwa kajok chedo. Seoul: Hyean, 2011.

14. Pak, Yongun. Koryŏ sidae ŭmsŏje wa kwagŏje yŏn'gu. Seoul: Ilchisa, 1990.

15. Palais, James B. "Confucianism and the Aristocratic/Bureaucratic Balance in Korea." Harvard Journal of Asiatic Studies 44, no. 2 (1984): 427-468.

16. Park, Eugene Y. Between Dreams and Reality: The Military Examinations in Late Chosŏn Korea, 1600-1894. Cambridge: Harvard University Asia Center, 2007.

17. Song, Mano. "The Wagner-Song Munkwa Project: Its Value For Historical Research.” Chŏnbuk sahak 32, (2008): 205-210.

18. Song, June-ho. "The Government Examination Rosters of the Yi Dynasty." In Studies in Asian Genealogy, edited by Spencer J. Palmer, 153-176. Provo: Brigham Young University Press, 1969.

19. Wagner, Edward W. "The Korean Chokpo as a Historical Source." In Studies in Asian Genealogy, edited by Spencer J. Palmer, 141-152. Provo: Brigham Young University Press, 1969.

20. Wagner, Edward W. "The Ladder of Success in Yi Dynasty Korea." Occasional Papers on Korea 1 (1974): 1-8.

21. Yi, Chaeok. Chosŏn sidae kwagŏ hapkyŏkcha ŭi tijit'ŏl ak'aibŭ wa inchŏk kwan'gyemang. P'aju: Pogosa, 2018.

22. Yi, Sŏngmu. Han'guk ŭi kwagŏ chedo. Seoul: Chimmundang, 1994. 
23. Yi, Sugŏn. Yŏngnam sarimp'a ŭi hyŏngsŏng. Kyŏngsan: Yŏngnam taehakkyo ch'ulp'anbu, 1990.

24. Yi, T’aejin. "16-segi yŏnhae chiyŏk ŭi ŏnjŏn kaebal: ch’ŏksin chŏngch'i ŭi kyŏngje chŏk paegyŏng iltan." Han 'guk sahoesa yŏn'gu. Seoul: Chisik sanŏpsa, 1986. 


\section{Snakes or Ladders? Measuring the Intergenerational Performance of Chosŏn's Munkwa Exam Candidates}

This interdisciplinary study measures the changes in intergenerational exam performance using a model of directed centrality values. Our test case explores the approximately 14,600 higher civil examination degree holders in the Munkwa database (Munkwa pangmok 文科榜目), in particular the underutilized records of each candidate's agnatic and affinal relations. Despite some imperfections in the data set, our provisional findings statistically demonstrate that the devastating Imjin War may have indeed been the watershed event responsible for the emergence of a new social order in seventeenth and eighteenth-century Korea. The network model, data structure, and the Python code developed for this study can be applied to other kinship and genealogical data from the Chosŏn dynasty 朝鮮 (1392-1910) and elsewhere.

Keywords: munkwa, network centrality, kinship data, quantitative history 
〈국문초록〉

\section{조선시대 문과 급제자 가문의 세대간 합격 여부 변화에 대한 정량적 측정}

나우영, Javier Cha (서울대학교)

본 논문은 네트워크 과학을 이용한 학제적 연구로, 방향성 네트워크의 중심성을 통 해 조선시대 문과 급제자 가문의 합격 여부 변화를 측정한다. 이 과정에서 약 14,600 명의 문과 방목 데이터베이스를 사용하며, 그 중에서도 활용도가 낮았던 과거 합격자 들의 혈연관계 자료에 집중한다. 본 연구는 해당 데이터의 부분적인 결함에도 불구하 고, 이를 통해 임진왜란이 실제로 17,18 세기 조선의 새로운 사회 질서를 형성하는 데 결정적인 전환점으로 작용했을 수도 있음을 통계적으로 시사한다. 이에 사용된 네트워 크 모델과 데이터 구조 및 파이선 코드는 조선시대를 비롯한 여타 친족 및 혈통 데이 터에도 적용될 수 있다.

주제어: 문과, 네트워크 중심성, 혈연관계 데이터, 계량사학 